\title{
Opportunistic Infections in Late Kidney Transplantation with Death Outcome: Case Report
}

\author{
Miriam Viviane Baron ${ }^{1,2 *}$, Carina Marangoni ${ }^{3}$, Michele Paula dos Santos ${ }^{3}$, \\ Célia Regina Martins Korzenieski ${ }^{4}$, Vitória Pereira Itaquy ${ }^{4}$, Tais Michele Werle ${ }^{3}$, \\ Gabriela Di Lorenzo Garcia Scherer ${ }^{3}$, Joice Nedel Ott'1, Marcus Vinicius de Mello Pinto5, \\ Janine Koepp 6 , Carolina Gonçalves Pinheiro7, Nathália Ken Pereira Iketani', \\ Cristine Brandenburg9 , Aline Ronis Sampaio5, Alexandre Sancho' ${ }^{10}$, \\ Danielle de Mello Florentino ${ }^{11}$, Bartira Ercília Pinheiro da Costa ${ }^{1}$ \\ ${ }^{1}$ Postgraduate Program in Medicine and Health Sciences of the Pontifical Catholic University of Rio Grande do Sul (PUC/RS), \\ Porto Alegre, Brazil \\ ${ }^{2}$ Coordination for the Improvement of Higher Education Personnel, Brazilia, Brazil \\ ${ }^{3}$ School of Medicine of the Pontifical Catholic University of Rio Grande do Sul (PUC/RS), Porto Alegre, Brazil \\ ${ }^{4}$ Schoolof Health and Life Sciences of the Pontifical Catholic University of Rio Grande do Sul (PUC/RS), Porto Alegre, Brazil \\ ${ }^{5}$ CelulareInstitute, Rio de Janeiro, Brazil \\ ${ }^{6}$ University of Santa Cruz do Sul (UNISC), Santa Cruz do Sul, Brazil \\ ${ }^{7}$ Postgraduate Program in Health Sciences of the Faculty of Medicine of ABC (FMABC), São Paulo, Brazil \\ ${ }^{8}$ Hospital Beneficiente Portuguesa of Belém, Pará, Brazil \\ ${ }^{9}$ Dom José Institute of Education and Culture/University of Vale do Acaraú (IDJ/UVA), Ceará, Brazil \\ ${ }^{10}$ Unigranrio University, Rio de Janeiro, Brazil \\ ${ }^{11}$ Uniredentor University, Rio de Janeiro, Brazil \\ Email: *miriambaron9@gmail.com
}

How to cite this paper: Baron, M.V., Marangoni, C., dos Santos, M.P., Korzenieski, C.R.M., Itaquy, V.P., Werle, T.M., Scherer, G.D.L.G., Ott, J.N., de Mello Pinto, M.V., Koepp, J., Pinheiro, C.G., Iketani, N.K.P., Brandenburg, C., Sampaio, A.R., Sancho, A., de Mello Florentino, D. and da Costa, B.E.P. (2021) Opportunistic Infections in Late Kidney Transplantation with Death Outcome: Case Report. Open Journal of Nephrology, 11, 171-182.

https://doi.org/10.4236/ojneph.2021.112014

Received: March 23, 2021

Accepted: May 10, 2021

Published: May 13, 2021

\begin{abstract}
Cytomegalovirus (CMV) and Pneumocystis jirovecii fungus are the main opportunistic microorganisms that affect transplanted individuals. Immunosuppressive drugs administered to prevent organ rejection leave the immune system vulnerable to these infections. The present report is about a kidney transplanted patient using immunosuppressants who was diagnosed with cytomegalovirus and pneumocystosis requiring admission to the intensive care unit (ICU). Female patient, 57 years old, a kidney transplanted three years ago, with comorbidities, such as systemic arterial hypertension, hypertriglyceridemia and type 2 diabetes mellitus. She was admitted to the hospital in January 2020 with a history of diarrhea, cough, malaise and weight loss of seven $\mathrm{kg}$ in a month. She made continuous use of the immunosuppressants tacrolimus ${ }^{\circledR}$ and mycophenolate sodium (MFS). After five days of hospitalization, she was transferred to the ICU due to refractory diarrhea, worsening renal function and respiratory pattern, requiring mechanical ventilation. Chest tomography showed changes
\end{abstract}


Copyright (c) 2021 by author(s) and Scientific Research Publishing Inc. This work is licensed under the Creative Commons Attribution International License (CC BY 4.0).

http://creativecommons.org/licenses/by/4.0/ that led to the diagnostic hypothesis of CMV pneumonia or Pneumocystis jirovecii. Treatment with Ganciclovir ${ }^{\circledR}$ and Bactrim ${ }^{\circledR}$ was started. The bronchial lavage polymerase chain reaction test confirmed the infectious condition for CMV and Pneumocystis jirovecii. Despite the drug therapy instituted, there was no improvement in the infectious condition. The patient started to present a general and progressive worsening of the clinical picture with loss of renal graft function, respiratory failure, metabolic acidosis, hemodynamic instability and severe distributive shock, evolving to death. In the present report, it was observed that after late kidney transplantation the fragility of the immune system caused by the use of immunosuppressants contributed to the development of a severe infection with CMV and Pneumocystis jirovecii. Adjusting the doses of immunosuppressants to individual needs can be an important measure for maintaining the proper immune system and consequently avoiding late opportunistic infections and death outcomes.

\section{Keywords}

Renal Transplantation, Infections, Opportunistic, Immunosuppressive Agent, Cytomegalovirus, Pneumocystis

\section{Introduction}

Kidney transplantation is performed to restore kidney function in patients with end-stage kidney disease, which can be caused by diabetes, hypertension, glomerulonephritis, polycystic kidney disease, chronic kidney disease (CKD), among other factors. In Brazil, approximately six thousand kidney transplants are performed each year [1], being the second country in absolute terms of kidney transplantation in the world. After transplant surgery, to avoid organ rejection, it is necessary to use immunosuppressants that control graft rejection and are primarily responsible for the success of the transplant. However, these drugs suppress immune responses contribute to many of the complications that can arise after a transplant, such as the appearance of cancer and the intensification of cardiovascular diseases and opportunistic infections [2]. Some of the most reported infections in the literature in renal transplanted patients are cytomegalovirus and pneumocystosis [3] [4].

Cytomegalovirus, or human herpesvirus 5 (CMV), is one of the main microorganisms that affect humans. The peculiarity of CMV is found in its latency after primary infection, because at any sign of low immunity there may be a reactivation of the infection. In transplanted patients, CMV is the most common agent in causes of infection, with an incidence ranging from $20 \%$ to $60 \%$ and the mortality rate can reach $90 \%$ [5]. In people with weakened immune systems, as in the case of transplanted recipients, CMV infection can cause serious diseases that affect the digestive system, central nervous system and retina.

Pneumocystosis is an opportunistic infection caused by Pneumocystis jirovecii fungus that is common in immunocompromised patients and can occur in indi- 
viduals with impaired innate immunity through corticosteroids, CMV infection, or lack humoral or cellular immune functions [6]. One study showed that up to one in five people may have Pneumocystis jirovecii DNA in the bronchoalveolar lavage fluid [7], thus suggesting the possibility of reactivating a previously established infection as being a potential cause of disease in susceptible hosts, such as in the case of kidney transplanted recipients.

The case presented here is a kidney transplanted patient using immunosuppressants who was diagnosed with cytomegalovirus and pneumocystosis, requiring admission to the intensive care unit (ICU). The patient had multiple comorbidities and presented opportunistic infections after late kidney transplantation, which is not commonly reported in the medical literature. Researchers [6] report that complications such as opportunistic infections in the short term after kidney transplantation commonly have favorable outcomes, unlike the case described here. The patient was recruited and accepted to participate in research carried out in the ICU with CAEE number: 91988318.6.0000.5336Brazil. The case is reported here for sharing with colleagues.

\section{Case Report}

Female patient, 57 years old, Brazilian, arrived at the hospital emergency room on 01/06/2020 complaining of persistent diarrhea, cough and malaise for about a month. She reported losing approximately seven $\mathrm{kg}$ in this period. Patient with a previous history of kidney transplantation three years ago, systemic arterial hypertension (SAH), hypertriglyceridemia and type 2 diabetes mellitus (DM). The patient used medications at home, such as tacrolimus, mycophenolate sodium (MFS), predsim $^{\circledR}$, hydrochlorothiazide ${ }^{\circledR}$, genfibrozil $^{\circledR}$, enalapril ${ }^{\circledR}$, formoterol $^{\circledR}$, in addition to recombinant human insulin (RHI).

The patient was transferred to the nursery on $01 / 08 / 2020$ for investigation of refractory diarrhea. After five days of hospitalization, she was transferred to the ICU due to tachypnea and worsening of the breathing pattern. Upon physical examination on admission to the ICU, the patient was lucid, oriented, communicative and spontaneously ventilating with slight respiratory effort. She was afebrile, without analgesication, with spontaneous diuresis, tachypneic and with metabolic acidosis. The score on the Simplified Acute Physiology Score 3 (SAPS 3) scale was 65 points and the probability of death was $46.13 \%$. She had systemic blood pressure (BP) 110/70 millimeters of mercury, heart rate (HR) 120 beats per minute, respiratory rate $(\mathrm{RR}) 32$ respiratory incursions per minute and oxygen saturation $\left(\mathrm{SpO}_{2}\right) 97 \%$. The laboratory data are displayed below on Table 1 .

Chest tomography revealed opacities with ground-glass attenuation diffusely distributed in both lungs, probably related to an infectious process by opportunistic germ, leading the medical team to consider a diagnostic hypothesis of CMV pneumonia or Pneumocystis jirovecii. Treatment with ganciclovir and bactrim was initiated for cytomegalovirus and/or pneumocystosis due to a previous history of kidney transplantation and continuous use of immunosuppressants and corticosteroids for immunosuppression. 
Table 1. Laboratory data of the patient.

\begin{tabular}{cc}
\hline Laboratory tests & Results \\
\hline Hematocrit & $26.1 \%$ \\
Leukocytes & $4.480 / \mathrm{UL}$ \\
Platelets & $147.000 / \mathrm{UL}$ \\
Creatinine & $3.60 \mathrm{mg} / \mathrm{dL}$ \\
Urea & $132 \mathrm{mg} / \mathrm{dL}$ \\
pH & 7.50 \\
Arterial lactate & $1.2 \mathrm{mmol} / \mathrm{L}$ \\
C-reactive protein (CRP) & $7.8 \mathrm{mg} / \mathrm{dL}$ \\
Prothrombin Time (PT) & $26.6 \mathrm{~seconds}$ \\
Potassium & $3.2 \mathrm{mEq} / \mathrm{L}$ \\
Sodium & $146 \mathrm{mEq} / \mathrm{L}$ \\
Magnesium & $2 \mathrm{mg} / \mathrm{dL}$ \\
Albumin & $2.5 \mathrm{~g} / \mathrm{dL}$ \\
\hline
\end{tabular}

Source: research data.

On $01 / 12 / 2020$, the patient worsened her breathing pattern and non-invasive ventilation (NIV) was started. During an attempt to remove NIV, the patient presented a drop in $\mathrm{SpO}_{2}$ and ventilatory support with invasive mechanical ventilation (IMV) was required. Acidosis was corrected with the infusion of sodium bicarbonate, however the prothrombin time was extended. During the day, the patient renal function worsened. The results of the CMV antigenemia and IgM sorology tests were negative. On 01/13/2020, the patient presented a score on the sequential organ failure assessment (SOFA) scale $=3$, quick SOFA $($ qSOFA $)=0$. Upon medical examination, the patient was without sedation, understanding and obeying commands, with isofotor-reactive pupils and mild dyspnea, which improved after adjustments in the IMV parameters. Lung auscultation showed crackling at the base of the right lung. Laboratory tests showed baseline creatinine of $4 \mathrm{mg} / \mathrm{dL}$, sodium $150 \mathrm{mEq} / \mathrm{L}$ and potassium $3 \mathrm{mEq} / \mathrm{L}$. The medical team suggested that hypernatremia and hypokalemia were due to the use of diuretics, which were discontinued.

On $01 / 14 / 2020$, the medical team considered the possibility of extubating the patient, two tests were performed with Ayre, but without success due to the abdominal press and hypoxemia, therefore she stayed with IMV without the need for sedation. The cytological examination, made from the bronchial aspirate collection, showed rare cylindrical hair cells: 150 cells with neutrophilic predominance. The SOFA score was 6 and qSOFA equal to 0 . On 01/15/2020, the patient continued to use ganciclovir, however the medical team didn't noticed any improvement in the infectious condition. Baseline creatinine showed a result of $1.8 \mathrm{mg} / \mathrm{dL}$. The patient persisted with diarrhea, hypernatremia and negative fluid balance. On 01/17/2020 she had a SOFA score of 4 and qSOFA 1 . On 01/18/2020, 
PT and hypernatremia were corrected and there was an improvement in renal function, however diarrhea persisted. Weaning was performed with Ayre, and the patient evolved with a good breathing pattern, then extubation was performed and NIV started. On 01/19/2020, the patient again presented hypernatremia, dyspnea and tachycardia. Reintubation and support with VMI were required. On this day, the patient received sedation with fentany $l^{\circledR}$ and proprofol ${ }^{\circledR}$ and the vasopressor norepinephrine ${ }^{\circledR}$. The result of the polymerase chain reaction (PCR) examination of the bronchial lavage was positive for cytomegalovirus and pneumocystosis.

On 01/20/2020, a bedside ultrasound was performed, showing pattern B in all pulmonary fields with confluent $B$ lines, indicating probable respiratory failure due to pulmonary congestion. Later on the same day, on physical examination, the patient had mydriatic and non-photoreactive pupils and distended abdomen. Blood gas analysis showed severe metabolic acidosis $\left(\mathrm{HCO}_{3} 11 \mathrm{mEq} / \mathrm{L}\right.$ and $\mathrm{EB}$ $-14.7 \mathrm{mEq} / \mathrm{L}$ ) partially compensated with $\mathrm{pH}$ 7.24. The result of the CRP test was equal to 3 , and the medical team considered the diagnosis of sepsis to be unlikely. The patient presented a worsening of pulmonary compliance. Added to that, she suffered a severe distributive shock demanding high doses of vasopressors, noradrenalineal at $0.88 \mathrm{mcg} / \mathrm{kg} / \mathrm{min}$ and vasopressin ${ }^{\circledR} 0.04 \mathrm{UI} / \mathrm{min}$. She also received doses of antibiotics, such as polymyxin $B^{\circledR} 500,000$ UI ( 5 bottles) and 2 grams of meropenem ${ }^{\circledR}$. In addition, the patient had severe hemodynamic instability, which did not allow hemodialysis, nor the transport to the radiology center for tomography. The patient had been worsening in her general condition and died after nine days of admission to the ICU due to CKD in the final stage. During the ICU stay, the patient used the medications: meropenem ${ }^{\circledR}, 5 \%$ glucose injectable solution, RHI, polymyxin $\mathrm{B}^{\circledR}$, sodium chloride, amiodarone ${ }^{\circledR}$, fentanyl $^{\circledR}$, etomidate ${ }^{\circledR}$, rocuronium $^{\circledR}$, furosemide $^{\circledR}$, sulfamethoxazole $^{\circledR}$, ganciclovir $^{\circledR}$, metoclopramide ${ }^{\circledR}$, anitidine $^{\circledR}$, heparin ${ }^{\circledR}$, hydrocortisone ${ }^{\circledR}$ and dipyrone ${ }^{\circledR}$.

\section{Discussion}

Organ transplantation is a possibility to improve the quality of life of people in the treatment of various diseases. Since the beginning of organ transplants, the kidneys were the first organs transplanted in a successful intra-abdominal open kidney transplant performed by Lawler in 1950 [8], thus, kidney transplantation offered new hope to patients with CKD by promoting a prolongation and an improvement in the quality of life [9]. After kidney transplantation, combinations of immunosuppressants are prescribed to prevent allograft rejection [10]. So, immunosuppressive agents decrease episodes of acute rejection and subsequent loss of organs, which leads to allografts with greater durability and longer survival for the patient [8].

The patient in this report underwent kidney transplantation three years ago and has been using immunosuppressants since then, such as MFS and tacrolimus ${ }^{\circledR}$. According to studies in animal models [11], the acceptance/tolerance of an allograft is an active process often determined by the presence of regulatory $\mathrm{T}$ 
cells (Tregs) [12]. In patients with allograft tolerance, several immune cells are involved in suppressing the adverse immune response. Regulatory B cells (Breg) produce immunosuppressive mediators, such as transforming growth factor (TGF) $-\beta$ and interleukin (IL) -10 , which inhibit the differentiation of CD4+ T cells with an inflammatory phenotype and proliferation of Treg cells. In addition, these mediators modulate the development of the main immune system suppressor cells, T cells. These cells, through various mechanisms, confer suppression to the immune system, mainly through immunosuppressive cytokines, M2-macrophage development and consumption of IL-2 [13].

In a clinical context, it is important to consider the effects of immunosuppressive drugs on Tregs. Treatment with calcineurin inhibitors, such as tacrolimus, reduces the viability and proliferation of Tregs [14], in the same way that it has been shown to inhibit the clonal expansion of virgin $\mathrm{T}$ cells and the development of cytotoxic and memory T cells [15]. The effects of MFS on Tregs appear to be more variable [16] [17] [18], while glucocorticoids do not appear to affect Tregs [19]. Thus, the patient in the present report received medications that prevented transplant rejection, but on the other hand left the immune system fragile and vulnerable to opportunistic infections. A meta-analysis [20] examined the results of patients with kidney transplantation whose primary immunosuppression was based on inhibitors of mTOR compared to immunosuppression based on calcineurin inhibitors, such as tacrolimus, and it was shown that patients treated with inhibitors of mTOR had a 51\% reduction in CMV infection compared to those treated with an antimetabolite associated with calcineurin inhibitor. The study also showed that the use of MFS is associated with a significantly higher risk of CMV events [21].

Another study [22] follows kidney transplanted patients and showed that, after one year of transplantation, 5 infections by $B K$ virus $(\mathrm{BKV})$ and 60 infections by CMV were recorded, which regression analyzes demonstrated that the only risk factor independent for the development of these opportunistic infections was the dose of tacrolimus which, in overdose, results in toxicity and opportunistic infections that have detrimental effects on renal allograft results [23] [24] [25] [26] [27]. In the present report, it can be seen that in addition to the fragility of the patient's immune system, the administration of the calcineurin inhibitor may also have contributed to the development of CMV infection. So, reducing the dose of immunosuppressants to suit the individual needs of the patient can prevent late opportunistic infections in kidney transplanted patients, consequently leading to increased survival.

One of the main causes of morbidity in immunocompromised patients is pulmonary infection by opportunistic pathogens. In general, CMV infections appear between the first to the sixth month after transplantation [28] and are not frequent after three years of transplantation, as occurred in the present report. CMV is a double-stranded DNA virus that replicates within cells using the host's cellular machinery, being the most common viral pathogen that occurs after kidney transplantation [21]. As soon as the patient was admitted, the possibility 
of an opportunistic infection arose due to the history of kidney transplantation, the continuous use of immunosuppressive drugs and the chest tomography, which showed opacities with ground-glass attenuation in both lungs. Thus, the medical team started the treatment with ganciclovir, which is the initial choice treatment for CMV infections [29] and bactrim due to the hypothesis of CMV pneumonia or Pneumocystis jirovecii. Pneumocystis jirovecii is an opportunistic fungal pathogen that causes life-threatening pneumonia in immunocompromised individuals, including patients with AIDS, cancer and organ transplants [30]. In addition, Pneumocystis jirovecii can occur in individuals with impaired innate immunity through corticosteroids, CMV infection, or lack of humoral or cellular immune functions [6].

In the present report, it is observed that the patient had several criteria of susceptibility to opportunistic infection by Pneumocystis jirovecii fungus, which can occur in the first six months, that is, in newly transplanted patients, being uncommon after three years of kidney transplantation [6]. Another important factor is that the use of calcineurin inhibitors in organ transplantation can also increase the incidence of Pneumocystis jirovecii infection [31] [32]. Therefore, in the present case, the presence of opportunistic infections contributed to an infectious condition that was difficult to control, contributing to the worsening of the patient's general condition.

The patient also had a difficulty to control hypernatremia. Hypernatremia is characterized by the concentration of sodium in the blood above $145 \mathrm{mEq} / \mathrm{L}$ per liter of blood. Disorders like this, called hydroelectrolytic disorders, are common in the clinical picture of sick patients admitted to the ICU and require special attention, because depending on the intensity, they can represent risk of death and sequelae to the patients [33]. The kidneys are the main route of sodium excretion, so if the kidneys are unable to properly perform their function, sodium can be retained in the body and cause various symptoms, such as fluid retention and weakness, with the central nervous system being the main organ reached [34]. The patient in the present report was kidney transplanted and, during the ICU stay, worsened her hypernatremia, which suggests a progressive worsening of renal function.

In addition, creatinine is one of the most used markers in the evaluation of renal function. It is a residual product of creatine, and its production is dependent on muscle mass and therefore does not present large daily variations [35]. Plasma creatinine levels reflect the glomerular filtration rate, since it can only be excreted by the kidney. High levels of creatinine indicate a deficiency in renal functionality, increasing significantly and rapidly in cases of renal failure [36]. In the present report, creatinine initially showed an upward curve and a subsequent decline, however, it maintained increased values during the ICU stay, showing impairment of renal function.

Another important factor to consider in the present case is the presence of comorbidities, such as DM and SAH. According to [37] [38], when the kidney transplant patient has DM, the risk of cardiovascular disease is high, which may 
determine a decrease in the survival and in the duration of the graft. However, due to the extensive cardiac evaluation that precedes kidney transplant surgery, cardiovascular causes are responsible for only one third of deaths, with noncardiovascular causes being responsible for two thirds of deaths. Although careful attention to universal preventive measures to reduce the risk of cardiovascular death can be useful in the diabetic population [39], efforts to improve long-term kidney transplantation in subgroups with diabetes will have to focus on reducing non-cardiovascular deaths, especially infections associated with types and dosages of immunomodulation [40]. In addition, in diabetic patients, the risk of complications associated with infection is five times greater. Moreover, SAH is considered an important cardiovascular risk factor and is suggested as a strong non-immunological predictor for graft and patient survival [41] [42]. Thus, despite all therapy instituted, the patient started to present a general and progressive worsening of the clinical picture, with respiratory failure, metabolic acidosis, hemodynamic instability and severe distributive shock, which, in addition to the opportunistic infections acquired in the late kidney transplantation, contributed to the patient's death.

\section{Conclusion}

In the present report, it was observed that after late kidney transplantation the fragility of the immune system caused by the use of immunosuppressants to prevent allograft rejection in a patient with comorbidities, such as SAH and DM, contributed to the development of severe infection by CMV and Pneumocystis jirovecii. The case evolved with loss of renal graft function and worsening of the general clinical picture, and despite the drug therapy instituted during the ICU stay for infection control, the patient died. Therefore, adjusting the doses of immunosuppressants to individual needs can be an important measure for the maintenance of an adequate immune system, and consequently avoid late opportunistic infections and death outcomes.

\section{Acknowledgements}

This study was funded in part by the Coordination of Improvement of Higher Level Personnel-Brazil (CAPES)_Finance Code 001.

\section{Conflicts of Interest}

The authors declare no conflicts of interest regarding the publication of this paper.

\section{References}

[1] Pacheco, L., Manfro, R.C., Pestana, J.O.M., Neumann, J., Filho, M.A. and Garcia, V.D. (2019) Dimensionamento dos Transplantes no Brasil e em cada estado (2012-2019). Registro Brasileiro de Transplantes, 4 Edition, 88. http://www.abto.org.br/abtov03/Upload/file/RBT/2019/RBT-2019-leitura.pdf

[2] Hertl, M. (2018)Visão geral dos transplantes-Imunologia. Manuais MSD edição para 
profissionais.

https://www.msdmanuals.com/pt/profissional/imunologia-dist\%C3\%BArbios-al\%C 3\%A9rgicos/transplante/vis\%C3\%A3o-geral-dos-transplantes

[3] Tibiriçá, C.S.B., Augusto, V.T., Castilho, L.F., Dragosavac, D., Faez, D.C.S. and Passos, A.I.M. (2016) Caracterização de infecções pulmonares no pós-operatório tardio de transplante renal: Uma revisão integrativa. Rev Bras Em Promoção Saúde, 29, 107-116. https://periodicos.unifor.br/RBPS/article/view/4324

[4] Souza, A.T.D. and Costa, J.R.D. (2013) A infecção por citomegalovírus em pacientes renais transplantados. Monografia [Trabalho de Conclusão de Curso apresentado como requisito parcial do curso de Bacharel em Enfermagem]-Faculdades Promove. http://nippromove.hospedagemdesites.ws/anais_simposio/arquivos_up/documento s/artigos/3c04d8d4781c6b88992104ecbcadec7c.pdf

[5] Ribeiro, I.F. (2016) Infecção ativa pelo citomegalovírus, em pacientes transplantados renais, detectada pela PCR em tempo real. Tese-Universidade Federal do Ceará, 59-59. https://pesquisa.bvsalud.org/portal/resource/pt/biblio-972007

[6] Fishman, J.A. (2020) Pneumocystis jiroveci. Seminars in Respiratory and Critical Care Medicine, 41, 141-157. https://doi.org/10.1055/s-0039-3399559

[7] Nevez, G., Jounieaux, V., Linas, M.D., Guyot, K., Leophonte, P., Massip, P., et al. (1997) High Frequency of Pneumocystis carinii sp. f. hominis Colonization in HIVNegative Patients. Journal of Eukaryotic Microbiology, 44, 36S. https://doi.org/10.1111/j.1550-7408.1997.tb05760.x

[8] Breda, A. (2018) Kidney Transplantation: The Beauty and the Beast. European Urology Focus, 4, 139. https://doi.org/10.1016/j.euf.2018.07.026

[9] Primc, D., Rački, S, Arnol M., Marinović, M., Fućak-Primc, A., Muzur, A., et al. (2020) The Beginnings of Kidney Transplantation in South-East Europe. Acta clinica Croatica, 59, 135-140. https://doi.org/10.20471/acc.2020.59.01.16

[10] Peeters, L.E.J., Andrews, L.M., Hesselink, D.A., de Winter, B.C.M. and van Gelder T. (2018) Personalized Immunosuppression in Elderly Renal Transplant Recipients. Pharmacological Research, 130, 303-307. https://doi.org/10.1016/j.phrs.2018.02.031

[11] Duran-Struuck, R., Sondermeijer, H.P., Bühler, L., Alonso-Guallart, P., Zitsman, J., Kato, Y., et al. (2017) Effect of EX Vivo-Expanded Recipient Regulatory T Cells on Hematopoietic Chimerism and Kidney Allograft Tolerance Across MHC Barriers in Cynomolgus Macaques. Transplantation, 101, 274-283. https://doi.org/10.1097/TP.0000000000001559

[12] Martin-Moreno, P.L., Tripathi, S. and Chandraker, A. (2018) Regulatory T Cells and Kidney Transplantation. Clinical Journal of the American Society of Nephrology, 13, 1760-1764. https://doi.org/10.2215/CJN.01750218

[13] Mirzakhani, M., Shahbazi, M., Oliaei, F. and Mohammadnia-Afrouzi, M. (2019) Immunological Biomarkers of Tolerance in Human Kidney Transplantation: An Updated Literature Review. Journal of Cellular Physiology, 234, 5762-5774. https://doi.org/10.1002/jcp.27480

[14] Scottà, C., Fanelli, G., Hoong, S.J., Romano, M., Lamperti, E.N., Sukthankar, M., et al. (2016) Impact of Immunosuppressive Drugs on the Therapeutic Efficacy of ex vivo Expanded Human Regulatory T cells. Haematologica,101, 91-100. https://haematologica.org/article/view/7611

[15] Nash, A., Samoylova, M., Leuthner, T., Zhu, M., Lin, L., Meyer, J.N., et al. (2020) Effects of Immunosuppressive Medications on Mitochondrial Function. Journal of Surgical Research, 249, 50-57. https://doi.org/10.1016/j.jss.2019.12.010 
[16] Demirkiran, A., Sewgobind, V.D.K.D., van der Weijde, J., Kok, A., Baan, C.C., Kwekkeboom, J., et al. (2009) Conversion from Calcineurin Inhibitor to Mycophenolate Mofetil-Based Immunosuppression Changes the Frequency and Phenotype of $\mathrm{CD}^{+} \mathrm{FOXP}^{+}$Regulatory T Cells. Transplantation, 87, 1062-1068. https://doi.org/10.1097/TP.0b013e31819d2032

[17] He, X., Smeets, R.L., Koenen, H.J.P.M., Vink, P.M., Wagenaars, J., Boots, A.M.H., et al. (2011) Mycophenolic Acid-Mediated Suppression of Human CD4+ T Cells: More than Mere Guanine Nucleotide Deprivation. American Journal of Transplantation, 11, 439-449. https://doi.org/10.1111/j.1600-6143.2010.03413.x

[18] Wu, T., Zhang, L., Xu, K., Sun, C., Lei, T., Peng, J., et al. (2012) Immunosuppressive Drugs on Inducing Ag-Specific $\mathrm{CD} 4{ }^{+} \mathrm{CD} 25^{+} \mathrm{Foxp}^{+}$Treg Cells during Immune Response in Vivo. Transplant Immunology, 27, 30-38. https://doi.org/10.1016/j.trim.2012.05.001

[19] Chen, X., Oppenheim, J.J., Winkler-Pickett, R.T., Ortaldo, J.R. and Howard, O.M.Z. (2006) Glucocorticoid Amplifies IL-2-Dependent Expansion of Functional FoxP3 ${ }^{+}$ $\mathrm{CD} 4{ }^{+} \mathrm{CD} 25^{+} \mathrm{T}$ Regulatory Cells in Vivo and Enhances Their Capacity to Suppress EAE. European Journal of Immunology, 36, 2139-2149.

https://doi.org/10.1002/eji.200635873

[20] Webster, A.C., Lee, V.W.S., Chapman, J.R. and Craig, J.C. (2006) Target of Rapamycin Inhibitors (Sirolimus and Everolimus) for Primary Immunosuppression of Kidney Transplant Recipients: A Systematic Review and Meta-Analysis of Randomized Trials. Transplantation, 81, 1234-1248. https://doi.org/10.1097/01.tp.0000219703.39149.85

[21] Malvezzi, P., Jouve, T. and Rostaing, L. (2016) Use of Everolimus-Based Immunosuppression to Decrease Cytomegalovirus Infection after Kidney Transplant. Experimental and Clinical Transplantation, 14, 361-366.

[22] Jung, H-Y., Seo, M.Y., Jeon, Y., Huh, K.H., Park, J.B., Jung, C.W., et al. ( 2020) Tacrolimus Trough Levels Higher than $6 \mathrm{ng} / \mathrm{ml}$ Might Not Be Required after a Year in Stable Kidney Transplant Recipients. PLoS ONE, 15, e0235418.

https://doi.org/10.1371/journal.pone.0235418

[23] Sagedal, S., Hartmann, A., Nordal, K.P., Osnes, K., Leivestad, T., Foss, A., et al. (2004) Impact of Early Cytomegalovirus Infection and Disease on Long-Term Recipient and Kidney Graft Survival. Kidney International, 66, 329-337.

https://doi.org/10.1111/j.1523-1755.2004.00735.x

[24] Arthurs, S.K., Eid, A.J., Pedersen, R.A., Kremers, W.K., Cosio, F.G., Patel, R., et al. (2008) Delayed-Onset Primary Cytomegalovirus Disease and the Risk of Allograft Failure and Mortality after Kidney Transplantation. Clinical Infectious Diseases, 46, 840-846. https://doi.org/10.1086/528718

[25] Ramos, E., Drachenberg, C.B., Wali, R. and Hirsch, H.H. (2009) The Decade of Polyomavirus BK-Associated Nephropathy: State of Affairs. Transplantation, 87, 621-630. https://doi.org/10.1097/TP.0b013e318197c17d

[26] Sellarés, J., de Freitas, D.G., Mengel, M., Reeve, J., Einecke, G., Sis, B., et al. (2012) Understanding the Causes of Kidney Transplant Failure: The Dominant Role of Antibody-Mediated Rejection and Nonadherence. American Journal of Transplantation, 12, 388-399. https://doi.org/10.1111/j.1600-6143.2011.03840.x

[27] Park, W.Y., Kang, S.S., Jin, K., Park, S.B., Choe, M. and Han. S. (2018) Long-Term Prognosis of BK Virus-Associated Nephropathy in Kidney Transplant Recipients. Kidney Research and Clinical Practice, 37, 167-173. https://www.ncbi.nlm.nih.gov/pmc/articles/PMC6027809/ 
https://doi.org/10.23876/j.krcp.2018.37.2.167

[28] Da Costa, Y.R.F. (2009) A Transplantação Renal, O Pós-Transplante Imediato. Master Theses, Faculdade de Medicina da Universidade de Coimbra, 76. https://estudogeral.sib.uc.pt/handle/10316/27553

[29] Chen, S-J., Wang, S-C. and Chen, Y-C. (2020) Antiviral Agents as Therapeutic Strategies against Cytomegalovirus Infections. Viruses, 12, Article No. 21. https://doi.org/10.3390/v12010021

[30] Bhagwat, S.P., Gigliotti, F., Wang, J., Wang, Z., Notter, R.H., Murphy, P.S., et al. (2018) Intrinsic Programming of Alveolar Macrophages for Protective Antifungal Innate Immunity against Pneumocystis Infection. Frontiers in Immunology, 9, Article No. 2131. https://doi.org/10.3389/fimmu.2018.02131

[31] Lufft, V., Kliem, V., Behrend, M., Pichlmayr, R., Koch, K.M. and Brunkhorst, R. (1996) Incidence of Pneumocystis carinii Pneumonia after Renal Transplantation: Impact of Immunosuppression. Transplantation, 62, 421-423. https://doi.org/10.1097/00007890-199608150-00022

[32] Hardy, A.M., Wajszczuk. C.P., Suffredini, A.F., Hakala, T.R. and Ho, M. (1984) Pneumocystis carinii Pneumonia in Renal-Transplant Recipients Treated with Cyclosporine and Steroids. Journal of Infectious Diseases, 149, 143-147. https://doi.org/10.1093/infdis/149.2.143

[33] Roman, R. and Traesel. M.A. (2006) Distúrbios hidroeletrolíticos na prática clínica diária. Acta Méd Porto Alegre, 1, 389-397.

[34] Gusmão, F. (2008) Hipernatremia. MedicinaNET. http://www.medicinanet.com.br/conteudos/revisoes/1344/hipernatremia.htm

[35] Sodré, F.L., Costa, J.C.B. and Lima, J.C.C. (2007) Evaluation of Renal Function and Damage: A Laboratorial Challenge. Jornal Brasileiro de Patologia e Medicina Laboratorial, 43, 329-337. https://doi.org/10.1590/S1676-24442007000500005

[36] Teixeira, L. (2013) Indicadores bioquímicos da função renal. Seminário apresentado na disciplina Bioquímica do tecido animal, no Programa de Pós-Graduação em Ciências Veterinárias da Universidade Federal do Rio Grande do Sul. https://www.ufrgs.br/lacvet/site/wp-content/uploads/2013/10/renalLiege.pdf

[37] Revanur, V.K., Jardine, A.G., Kingsmore, D.B., Jaques, B.C., Hamilton, D.H. and Jindal, R.M. (2001) Influence of Diabetes Mellitus on Patient and Graft Survival in Recipients of Kidney Transplantation. Clinical Transplantation, 15, 89-94. https://onlinelibrary.wiley.com/doi/epdf/10.1034/j.1399-0012.2001.150202.x https://doi.org/10.1034/j.1399-0012.2001.150202.x

[38] Cosio, F.G., Pesavento, T.E., Kim, S., Osei, K., Henry, M. and Ferguson, R.M. (2002) Patient Survival after Renal Transplantation: IV. Impact of Post-Transplant Diabetes. Kidney International, 62, 1440-1446. https://doi.org/10.1111/j.1523-1755.2002.kid582.x

[39] Carpenter, M.A., Weir, M.R., Adey, D.B., House, A.A., Bostom, A.G. and Kusek, J.W. (2012) Inadequacy of Cardiovascular Risk Factor Management in Chronic Kidney Transplantation-Evidence from the FAVORIT Study. Clinical Transplantation, 26, E438-E446. https://doi.org/10.1111/j.1399-0012.2012.01676.x

[40] Weinrauch, L.A., D’Elia, J.A., Weir, M.R., Bunnapradist, S., Finn, P.V., Liu, J., et al. (2018) Infection and Malignancy Ou.egh Cardiovascular Mortality in Kidney Transplant Recipients: Post Hoc Analysis of the FAVORIT Trial. The American Journal of Medicine, 131, 165-172. https://doi.org/10.1016/j.amjmed.2017.08.038

[41] Opelz, G., Wujciak, T. and Ritz, E. (1998) Association of Chronic Kidney Graft Failure with Recipient Blood Pressure. Kidney International, 53, 217-222. 
https://doi.org/10.1046/j.1523-1755.1998.00744.x

[42] Weir, M.R. (2004) Blood Pressure Management in the Kidney Transplant Recipient. Advances in Chronic Kidney Disease, 11, 172-183.

https://doi.org/10.1053/j.arrt.2004.01.004 